\title{
VI North Caucasus Organic Chemistry Symposium NCOCS-2022
}

The international conference "VI North Caucasus Organic Chemistry Symposium NCOCS-2022" will be held on April 18-22, 2022, at the North Caucasus Federal University in Stavropol.

\section{Organizers}

North Caucasus Federal University

D. I. Mendeleev Russian Chemical Society.

Organizing Committee

\section{Chairperson}

Vice-Chairpersons

Co-chairpersons
Professor A. V. Aksenov

Professor I. V. Aksenova, M. A. Rubin

Program Committee

Academician of the RAS I. P. Beletskaya, Professor V. N. Gevorgyan

\section{Scientific Program}

The scientific program of the Symposium includes the following areas:

- fundamental aspects of organic chemistry;

- new trends in the development of organic chemistry;

- new conceptual approaches related to physicochemical properties and practical use of organic compounds;

- medicinal chemistry.

The Conference program would include plenary lectures $(40 \mathrm{~min})$, keynote lectures $(30 \mathrm{~min})$, invited lectures (20 $\mathrm{min})$, oral reports (15 $\mathrm{min})$, and poster session.

The working languages of the Symposium are Russian and English.

The Symposium is planned to be attended by a number of prominent foreign and Russian scientists. The following scientists agreed to participate in the Conference: Academicians of the RAS V. P. Ananikov, I. P. Beletskaya, and V. N. Charushin (Russia); Corresponding Members of the RAS I. S. Antipin and A. O. Terentiev (Russia); Professors Sh. Kobayashi (Japan), V. Gevorgyan (USA), A. Echavarren (Spain), W. F. A. Dehaen (Belgium), I. V. Alabugin (USA), J. K. de Brabander (USA), V. V. Fokin (USA), D. Maiti (India), A. V. Malkov (UK), S. Tsogoeva (Germany), and V. G. Nenaidenko (Russia).

Contacts: Stanislav Vladimirovich Shcherbakov, phone.: +7 (988) 114 8883; E-mail: aaksenov@ncfu.ru. Professor Aleksandr Viktorovich Aksenov, phone: 7 (918) 743 0255; E-mail: aaksenov@ncfu.ru. Professor Inna Valer'evna Aksenova, phone: +7 (918) 743 0257; E-mail: iaksenova@ncfu.ru.

https://hetchem.ru/ 